\title{
Globalism or Nationalism? The Paradox of Chinese Official Discourse in the Context of the COVID-19 Outbreak
}

\author{
Yifan Yang ${ }^{1}$ (D) Xuechen Chen $^{2}$
}

Accepted: 11 September 2020 / Published online: 16 September 2020

(C) Journal of Chinese Political Science/Association of Chinese Political Studies 2020

\begin{abstract}
By employing discourse-historical approach and corpus linguistics, this paper examines media reports to analyze the Chinese official discourse in the context of the COVID-19 outbreak. The results demonstrate that a paradox of globalism and nationalism has been simultaneously reflected when reporting the global pandemic. Based on a polarizing discursive construction of positive "self" and negative "others," on many occasions, the globalist and nationalist arguments have been closely intertwined and complement each other to reinforce the legitimacy of the ruling party at home and the international reputation of China under the leadership of the ruling party.
\end{abstract}

Keywords Globalism · Nationalism, national identity · Identity discourse · COVID-19 . China

\section{Introduction}

The future of globalization has been overshadowed by the coronavirus outbreak in the early 2020s as has changed the landscape of world politics in opposing directions. On the one hand, global leaders are calling for more cooperation on global health while, on the other hand, they exacerbate nationalist sentiment for tighter border control against globalization. Although not the only case, China is frequently in the spotlight due to the China-centered global supply chains and their growing impact on globalization at a

Yifan Yang

yangyifanblue@gmail.com

Xuechen Chen

xuechen.chen@nchlondon.ac.uk

1 Department of Politics, East China Normal University, Shanghai, China

2 Faculty of Politics and International Relations, New College of the Humanities, London, UK 
time when the US-led Western world refrains from assuming global responsibility [39]. China was the first country that reported the confirmed cases of coronavirus to the World Health Organization (WHO) and has pioneered in promoting global cooperation after the declaration of a global pandemic. This is consistent with China's longstanding diplomatic discourse on globalism after the 2008-2009 global financial crisis, evident in its official discourse on the "Community of Shared Destiny for Mankind" and "Global Community of Health for All." Chinese top leaders publicly emphasize the importance of international cooperation against COVID-19, to protect global public health by proactively collaborating with multilateral institutions such as the United Nations, the WHO, and other G20 countries and providing funding and clinical support for developing countries affected by the global pandemic [60]. Chinese officials argued that leading global cooperation, upholding multilateralism, supporting vulnerable regions, and strengthening macro policy coordination are essential in Chinese foreign policies in response to the COVID-19 outbreak [63].

However, nationalist sentiment had also been rising after COVID-19 spread was successfully curbed in mainland China in less than 3 months. Chinese mass media that has long been serving as the mouthpiece of the Chinese Communist Party (CCP) [54] frequently hailed the superiority of Chinese political system and praised President $\mathrm{Xi}$ Jinping's leadership when reporting anti-epidemic efforts. This is evident in the news reports that self-congratulate the nation's containment of the pandemic and downplay other nations' performances. This nationalist sentiment encourages the Chinese population to actively promote "positive energy" while ignoring dissenting opinions disclosing the mishandling of the crisis during the early days of the COVID-19 outbreak [33]. Some media accounts even pointed out with pride that Western countries can only learn from Beijing's experience and "copy China's homework" - to implement the same measures to contain the epidemic [17]. It seems that Chinese mass media send contradictory messages to the world: supporting globalism and upholding nationalism in the same contexts.

At first sight, these two contradicting positions in the spectrum of Chinese national identity discourse are easily explained. As explained by Shambaugh, globalist discourse at one extreme of the spectrum has been highlighted when talking about China's interaction with globalzaization, and nationalist discourse at the opposite end when highlighting China's domestic stability [50]. However, as this paper argues, the Chinese official discourse is seemingly paradoxical when reporting the COVID-19 outbreak, as it jointly promote both globalism and nationalism at the same time and constructs its globalist discourse in a nationalist manner. The result is a polarizing discursive construction of "us" and "them." Ironically, the paradox between the two extremes of nationalism and globalism in the Chinese official discourse seems to harmonize the two discourses as they now complement each other to better serve the interests of China and the domestic legitimacy of the ruling party.

To explain this paradox within Chinese political discourse, discourse analysis is an entry point. The core of this study is the Chinese official discourse in the mass media that engages in "othering" when representing Western countries as "them" or "others" relative to China as "us" or "the Self," leading to "heteronomization" or discursive construction of an outgroup and a threatening stranger that is different from the constructed "in-group" [38]. To study the Chinese official discourse, this paper will utilize Discourse-Historical Approach (DHA, a major variant of critical discourse 
analysis) and corpus linguistics (CL). These approaches were chosen because, critical discourse analysis as a qualitative approach studies discourse as a circular process in which social practices (language use) influence texts by shaping the context and mode in which they are produced, and in turn, texts influence society by shaping the attitudes of those who read or otherwise consume them [21]. In addition, corpus linguistics (CL) is a quantitative approach to examining collocational and other recurrent patterns associated with specific lexical items [2].

Combining these two approaches (that will be elaborated later) together, this paper examines the news reports targeting domestic and international readers of the top five official media outlets in China on the COVID-19 outbreak. In doing so, it firstly identifies how the paradox of Chinese official discourse has been represented in news reports and why it is represented in this manner. Secondly, it discusses the discourse's effects on Chinese international relations. Moreover, looking at Chinese official discourse in the context of COVID-19 outbreak will contribute to the understanding of China in global health governance. On the one hand, it will shed light on China's attitude towards multilateral institution in global health governance and global governance more widely and provide insight into China's attempts to change global COVID19 narrative [57]. On the other hand, to what extent the Chinese experience of controlling the epidemic may be applied to other countries is debatable, but promoting this line of global policy learning is invaluable in global health governance [28].

The reminder of this paper consists of four parts. The first part will look at the relationship between mass media, national identity and identity discourse, which is followed by a discussion on globalism and nationalism as two extremes in Chinese official discourse. By analyzing the top five official media outlets (three in Chinese and two in English), the third part will look at how globalist discourse and nationalist discourse have been intertwined and approve that these two paradoxical discourses can be complementary to serve the same objectives. The fourth part is a short discussion and conclusion. This study adds to the debate on globalism and nationalism, and also contributes to a larger body of academic literature on public health and global governance $[14,24,31,56,58]$.

\section{Mass Media, National Identity, and Identity Discourse}

An identity is whatever makes a thing what it is in the philosophical sense, but identity is too ambiguous for discussion when it applies to an object such as a nation. Notably, national identity has been widely studied in different disciplines. It is a theoretical object that can be understood as a type of variable with explanatory power; something shaped by various social conditions external to it in structural terms; or something structured through institutions, individuals, and "discourse" within an "imagined community" from a constructivist perspective [29]; it is rooted in what all its members share not individually but collectively, not privately but publicly, and has an inescapable institutional focus [47]; it revolves around the past, present, and future - the three temporal axes of a nation [59].

National identity can be differentiated between internal identity and external identity [36]. When studying the international behaviors of a nation-state and predicting its policy directions, internal and external identities must be considered in conjunction, 
since internal identities are the root of external identities and cannot be separated from each other. Accordingly, this paper does not distinguish external identities from internal identities because they both help project a nation-state as an international actor in world politics. However, considering that identities, either individual or collective, develop from drawn-out processes of both internal and external interaction over a long period, they do not change within a short time [10]. Consequently, in this paper, we assume national identities are relatively stable constructs when using them within concrete domestic and international occasions.

What is essential in the political discourse of national identity are the maintenance of a boundary and the dichotomization between members and outgroups, because they lead to a sense of belonging by closing out others, by which self-esteem and internal solidarity is to be built [27]. Arguably, there are two - one symbolic and one behavioral - dimensions of the construction. In addition, there is also a boundary and the continuous dichotomization between insiders and outsiders. In terms of the former, the cognitive notion of "us" and "them" has been created through discourse - language in use in spoken and written form; regarding the latter, social closure occurred through discrimination of members of the other group, which can be coupled with a symbolic dimension [32]. Equating the nation-state to a unitary actor when discussing identity formation is problematic, but a nation-state is analogous to a "group Self, capable of group-level cognition." Humanizing the nation-state has been commonly applied in studies of collective identity [8]. In this sense, applying discursive construction of the self-other dialectic has been meaningful in studies of national identity.

In this context, what role do mass media play in the construction of national identity? Although many factors - state related (or more specifically its administers and officials), political, institutional, media, and everyday social practices - are contributing to the formation of national identity [59], it is a common practice nowadays that news making in the media outlets plays a vital role in the formation and expression of modern national consciousness $[25,26]$. Admittedly, while travels within nations and across borders are increasing, much of the contact and experience that individuals gained on populations and cultures of other nations are through media texts. Because nations are a political community of large dimensions and structural diversity, the prevalence of media outlets that can approach large audiences are the ideal distributor and multiplier of pro-national information. During this process, media outlets satisfy the needs of a mass audience in virtue of conveying positive media representation of the audience groups and devaluating the stereotyping foreign nations. This not only leads to a stronger identification with the own nation at the individual level and an increase in cohesion as a political community at the societal level but also to another side effect: the othering of foreign nations and ethnicities [44].

Nevertheless, the rapid development of information and communication technologies has changed the ecology of mass media to such extent that a variety of news sources on the internet are available for information seeking. Consequently, the role of traditional mass media as integrators of nations or more specifically governments has been eroded [19]. An examination of the impact of internet communication on information, power, and freedom distribution in democratic and authoritarian countries indicates that power distribution and freedom distribution work together to neutralize and regulate the influence of information distribution [41]. In other words, the internet as a tool has been domesticated by social and individual predispositions from the 
perspectives of the social construction of technology, helping consolidate national identity. As a result, State authorities can employ mechanisms to control the internet that originally seem uncontrollable and self-expanding, making the internet gradually reproduce the features of traditional media and join national media systems [19]. Accordingly, Müller [44] views national identity building as a mediated process, which also works in the age of internet communication. Nevertheless, media exposure encourages readers to observe the world in national terms and think about their nation in patriotic terms.

CDA is commonly considered a point of entry into the user's identity. It uncovers how a polarizing discursive strategy is employed to highlight the negative characters of the Other and the positive aspects of the Self while marginalizing the positive attributes of the other and the negative behaviors of the Self [38]. Discourse, when defined widely, includes language, encompassing for example, signs, semiotics, and gestures, but also refers to how the world is ordered through social practice [20]. Thus, discourse-based understandings of identity allow the understanding of how identities are maintained, reproduced, and normalized in everyday texts and practice of interaction [7]. For mass media, media representations are a reconceptualization of observable linguistic markers based on the specific intentions of those involved in media production. Regarding the dual role that mass media play in the formation and expression of national identity, Madianou [42] suggests top-down and bottom-up approaches to study the relationship between mass media and national identity: the top-down approach highlights how mass media is manipulated to create a sense of national identity among the masses, and the bottom-up approach indicates how cultures and identities as lived and performed in discourse, which has been reflected in mass media. In the context of the relationship between mass media and national identity, media discourse is understood in terms of its content and as an intention that reorganizes and regulates other discursive practices into a new order [40].

This paper equates media discourse to political (official) discourse, but the complicated relationship between government and mass media in China cannot be overlooked. Notably, the CCP allows news outlets (e.g., newspapers, magazines, television programs) to compete for market share instead of relying on government financing; thus, the CCP has relinquished its monopoly in the provision of information to the public [51]. However, the increased marketization does not result in fewer political constraints because the content production of news outlets remains under strict state control, putting the production of meaning under the dual-pressure of state control and the market [26]. By following the political rules exercised by the ruling party, media coverage has been largely determined by the official response to the event being covered, which further strengthens self-censorship and increases the homogeneity of the news content.

In summary, because news narratives on mass media play a vital role in establishing political consensus, national identity can be articulated in terms of principles of "us" and "them" by identifying their differences [15]. Therefore, mass media help the discursive construction and symbolic representation of national identity by drawing on the logic of "the self" and "the other" or "us" and "them." Accordingly, analyzing media discourse on national identity can facilitate an understanding of political (official) discourse in China, particularly in terms of identity performance in during a global public health crisis such as the COVID-19 outbreak. 


\section{Political Discourse on China's National Identity: Between "Nationalism" and "Globalism"}

China as an emerging power pays more attention than other states to its discourse power strategy. How it defines its perspectives and expresses itself has a decisive influence on its relationship with established powers in international politics and the world structure [65]. However, the political discourse on China's national identity can range from nationalist tendencies on the left to globalist tendencies marked by the full engagement in multilateral institutions and global governance on the right. Again other discourses on national identity progress from a more realistic to a more liberal orientation in between the two extremes [50]. In China, the complicated relationship between nationalism and globalism continues to be highly debated, in particular in regard to whether nationalist ideology and the role of nation-states in world politics will be strengthened or whether globalism will gradually dominate at the expense of nationalism.

Nationalism matters in Chinese official discourse. According to Smith [52], nationalism is "a sentiment or consciousness of belonging to the nation," among the range of meanings associated with it. In the early years after the P. R. China was founded, Chinese nationalism is constructed by emphasizing China as a victim of foreign invasion and ill-treatment through Western countries' economic, political and ideological power [57, 67]. More recently, by praising China's performance and achievements under the leadership of the ruling party and criticizing Western countries' interference, the Chinese government/party-state counters criticism of Western countries and sustains the legitimacy of the ruling party at home [67]. Since the early 1990s, nationalism has become another vision of ideology employed by the CCP to legitimize the ruling party to counter the belief vacuum arising fromthe decline in the Maoist faith and the so-called "intrusion of Western ideology" $[13,66]$. Chinese nationalism has been promoted through a top-down approach in an instrumentalist fashion, which involves blatant fabrication of facts and selective remembering and partial forgetting of the nation's historical and cultural legacy [64].

By contrast, globalist discourse also rises in recent years in China. Globalism starts from "where human beings assume obligations toward the world as a whole, where they expose values which take the globe as their frame or reference point" [1]. This has been further developed into a "the dominant ideology and subjectivity associated with different historically-dominant formation of global extension" [30]. Globalism's most obvious expression is in the worldwide green movement and sustainable development and penetrates such areas as health, gender equality, and human rights more generally [1]. Nye [46] posits that globalism - understood as the density of networks of interdependence - does not imply universality but that different relationships of interdependence intersect more deeply at more different points. Hence, globalists realize the limits of sovereignty in managing non-traditional challenges across national borders and embrace multilateral institutions [50]. Moreover, globalism is viewed as the spatial extension of social relations worldwide and associated with globalization due to capitalist expansion [30]. However, it is also of political nature because the political tasks of the nation-states are being increasingly globalized because of global problems that cannot be managed by nation-states alone, including the United States, the most powerful nation in the world. Consequently, managing global problems and the high 
speed of globalization should be differentiated from government-centered values through advocating globalism and respecting values and ideas [11].

According to Çınar [16], "globalism is a product of nationalism," meaning globalism makes sense in national discourse because global-local dichotomization can be understood as the relationship between "them" and "us." Therefore, globalism is about how to produce and project a particular image of the world in the local context when portraying "us" against the "global-other" to empower a particular national identity. For Zheng [66], nationalism seems to serve as a strong power against globalization, especially globalization characterized by Westernization. In this sense, nationalism and globalism seem to be in tension. However, these two concepts do not necessarily contradict each other, not because nationalism produces globalism, but because globalism augments nationalism $[12,50]$. Also, these two extremes can be complementary when they both are constructed through an "us" versus "them" dichotomization in political discourse to serve the same objectives. Whether examining the Chinese official discourse of nationalism and globalism in general or these two ideologies reflected in the context of the COVID-19 outbreak in particular, both views seem to be reasonable explanations.

Despite benefiting from economic globalization, China's globalism aims to find an alternative means to access the global market in order to maintain its economic development at a high speed without merging into the Western-based international system. With its increasing strength and capability, China also intends to reassure its influence proportional to its growing power in global governance under the leadership of the ruling party [62]. The first driver behind China's intention to join world politics is to "reform within" the current system in order to better serve the interests of China as an emerging power [6], seeming to imply China as an outward-looking country. However, China is basically an inward-looking rather than an outward-looking country [12], as China still has plenty of problems at home influencing its further development. A great challenge faced by the ruling party is to deepen the reform to accommodate the new and diverse changes in economy, politics and society without losing its control at home [23]. Albeit a growing number of Western countries are encouraging China to take on more responsibilities commensurate with China's growing economic power in international politics, China is not complying. Admittedly, China would like to be regarded as a responsible international actor on the world stage but not as a domineering leader, as maintaining internal stability still comes first.

The COVID-19 outbreak has strengthened nationalism and globalism, as demonstrated in China's political discourse. The nationalist discourse in Chinese mass media results from fear and confidence. In the early days of the COVID-19 outbreak, China was blamed for its botched response in the initial stages of combating this new type of coronavirus because reports indicate that COVID-19 spread from a seafood market in Wuhan, in central China [57]. Either calling for an inquiry into the origin of the virus or finding a scapegoat for their failure to contain the spread of the contagion or both, Western countries blame China for its bad governance, insufficient transparency, and unwillingness to share information and are demanding reparations [18]. These can threaten China's standing in world affairs and jeopardize the legitimacy of the CCP at home as the influx of foreign news reports about the COVID-19 outbreak deteriorates domestic public opinion and reduces public support for the governmental directives. Consequently, Chinese foreign affairs departments have taken an increasingly strident 
tone against criticism from Western countries, irrespective of their reasons. The "wolfwarrior diplomacy" seems to be a new normal for Chinese diplomacy [68]. Being the first country to have successfully contained the virus, self-congratulations for its achievements and downplaying the attempts of other countries to contain the virus has been added to China's nationalist discourse. However, this is done without considering whether the measures such as the fierce lockdown and impositions on freedom of movement can be deployed in other countries of different political systems [9]. From fear to confidence, Chinese nationalist sentiment has been changing from refusing criticism from Western countries to criticizing Western countries.

In the context of the COVID-19 outbreak, the Chinese official discourse of globalism has been increasing, also reflecting a polarizing discursive strategy. The side effects of globalization, such as the global pandemic, call for cooperation among actors in a world without a central authority. In a newly published paper, Zhang [63] states that COVID-19 can spread to any person in any country and that China provided extra time for all other countries by building a crucial line of defense. Therefore, beyond providing a model for containing the spread of COVID-19, China has leveraged its role as the global manufacturing hub by exporting personal protective equipment and ancillary medical equipment as a public good. It has also been a responsible power relative to the US-led Western world by providing necessary funding to developing countries and multilateral institutions such as WHO, and offering medical aid to countries in need [55]. This has allowed China to boost its image as a global leader in this crisis. However, globalist discourse is reflected by highlighting China's willingness to cooperate and contribute to global public goods. It is upholding the discourse of a "Community of Shared Community for Mankind", in comparison with Western countries' insufficient efforts to deliver effective measures domestically and to commit to multilateral institutions internationally. Chinese official media outlets widely cover the stories about a growing number of the confirmed cases in America as a "new epicenter", the coldblooded "herd immunity" and the widespread "political virus" jeopardizing international cooperation in fighting against the COVID-19. To be more specific, the globalist discourse has been constructed in a nationalist manner by praising China and downplaying Western countries.

When looking at the news reports regarding the COVID-19 outbreak, globalism and nationalism as the two extremes of China's national identity co-exist. On the one hand, the globalist discourse is favored in official discourses as demonstrated below, but it has been constructed in a nationalist manner. It highlights China's support for international cooperation but might generate more suspicion of Western countries if Chinese official media outlets keep downplaying the anti-pandemic efforts made by Western countries. On the other hand, nationalism and globalism complement each other to sustain the legitimacy of the ruling party at home. The nationalist discourse selfcongratulates China on containing the virus and globalist discourse marked by projecting China as a model of global governance of the worldwide pandemic. Both discourses criticize the Western countries' demonization of China by highlighting its performance relative to the failure of Western countries, demonstrating how mass media acts as the mouthpiece of authority in guiding public opinions [61]. In this case, nationalism and globalism in the media and the official discourses have been constructed based on the same logic of the "us" and "them" dichotomization and harmonized in sustaining the legitimacy of the CCP at home. Therefore, the following 
empirical section will illustrate how the seemingly paradoxical discourses between globalism and nationalism that have been studied before have been complementing each other in mass media reports about the COVID-19 outbreak in China.

\section{Media Representation of the COVID-19 Outbreak in China}

\section{Methodology}

To examine the media representation of the COVID-19 outbreak in China, we draw on an integrative combination of methodological approaches associated with CDA and CL. CDA can be broadly defined as an academic movement or a method of conducting discourse analysis from a critical perspective [5]. CDA has been widely adopted to explore concepts such as power, ideology, and domination [2, 5] and is particularly suited for understanding the role of language in the construction of power relations, exclusion, values, and identities in news texts [53]. We are aware of the many CDA approaches with their different research focuses and adopt the discourse-historical approach (DHA) - a major variant of CDA primarily concerned with identifying the themes of a given discourse, adopting detailed analysis of linguistic and discursive strategies, and examining how these discursive practices contribute to shaping particular social relationships and identity constructions [59].

In the context of this research, DHA entails a two-dimensional process. The first step of DHA aims to identify the key content, themes, or topics of a given corpus. As explained later, combined with keyword analysis, the first phase of DHA provides an overview of a news story and an understanding of the dominant discursive topics in the corpora. DHA also helps reveal the extent to which nationalism and globalism are prominent frames in the press coverage of the COVID-19 outbreak. The second step investigates discursive strategies and linguistic means deployed in the news texts. The empirical analysis in this step examines how three discursive strategies (i.e., nomination, predication, argumentation) are used in the corpora to construct a globalist and/or nationalist stance in China's media representation of the COVID-19 outbreak (Table 1).

Furthermore, we use another methodological approach-CL-to complement DHA. CL is an approach for conducting quantitative research on a large volume of text [4], allowing researchers to explore collocational and other recurrent patterns associated with specific lexical items [2]. Therefore, CL can be used to examine sematic patterns, discursive functions, and collocational environments by analyzing keywords, frequency of lexis, collocations, and concordance lines in a large amount of language data [5]. CL has been adopted to effectively study discourse across various social domains, including the media and politics [5, 22, 48]. Notably, proponents of CDA in general and DHA in particular have been eager to draw on multi-method research designs to address the frequently raised criticism of CDA. For instance, traditional CDA often used qualitative research to examine small samples, undermining the CDA's validity and generalizability [35]. Adopting CL methods enables researchers to use a larger volume of samples and thus increase the level of rigor in data analysis [5].

In this paper, CL is deployed in parallel with DHA and is a complementary tool throughout the two-step process of DHA analysis. To be specific, we adopt CL to 
Table 1 A summary of discursive strategies in DHA [5, 49]

\begin{tabular}{|c|c|c|c|}
\hline $\begin{array}{l}\text { Discursive } \\
\text { strategy }\end{array}$ & Objective & Question & Language indicator \\
\hline Nomination & $\begin{array}{l}\text { Discursive construction of } \\
\text { social actors, objects, } \\
\text { phenomena, and events }\end{array}$ & $\begin{array}{l}\text { How are the chosen identity } \\
\text { labels named and referred to } \\
\text { linguistically? }\end{array}$ & Noun collocates \\
\hline Predication & $\begin{array}{l}\text { Labeling social actors } \\
\text { more or less positively } \\
\text { or negatively, } \\
\text { deprecatorily or } \\
\text { appreciatively }\end{array}$ & $\begin{array}{l}\text { What traits, characteristics, and } \\
\text { features are attributed to } \\
\text { these chosen subjects? }\end{array}$ & Adjective collocates \\
\hline Argumentation & $\begin{array}{l}\text { Justification and } \\
\text { questioning of positive } \\
\text { or negative attributions }\end{array}$ & $\begin{array}{l}\text { By means of what arguments } \\
\text { and argumentation schemes } \\
\text { are certain representations of } \\
\text { the subjects justified, } \\
\text { legitimized and naturalized } \\
\text { in discourse? }\end{array}$ & $\begin{array}{l}\text { Topos in the concordance lines } \\
\text { (Within argumentation } \\
\text { theory, topoi can be } \\
\text { understood as the parts of } \\
\text { argumentation of the } \\
\text { required premises. Topos } \\
\text { constitute the formal or } \\
\text { content-related warrants or } \\
\text { conclusion rules that con- } \\
\text { nect arguments with con- } \\
\text { clusions or claims. In other } \\
\text { words, topos can justify the } \\
\text { transition from argument to } \\
\text { conclusion) }\end{array}$ \\
\hline
\end{tabular}

analyze three aspects of the corpora: keyness, collocation, and concordance [3]. Keyness is analyzed on the basis of the high frequency of particular words (also termed keywords). As aforementioned, keyword analysis can be used in conjunction with DHA to identify terms that are significantly more frequent in texts and can contribute to establishing the key discursive themes. Collocation refers to the co-occurrence of two words when the frequency of the co-occurrence is above the chance that is statistically determined. Collocation analysis provides information on the most salient characteristics associated with a word (or a selected group of words). Furthermore, concordance analysis shows a list of a given word or word cluster with its co-text on either side [3].

\section{Data Analysis Procedures}

This research entails two corpora of news texts comprising 1,058,665 tokens. ${ }^{1}$ The English language corpus is retrieved from PreQuest and contains at least one of the following search terms ("new coronavirus," "COVID-19") published in China Daily and Beijing Review. The Chinese language corpus is downloaded from CNKI and includes at least one of the following search words (“新冠肺炎”, “新冠疫情”) published in People's Daily, Guangming Daily, and Xinhua Daily News. The English and Chinese corpora were published between January 1 and May 15, 2020. Two important reasons are behind the selection of these five newspapers. First, these newspapers are leading national newspapers that play a significant role in shaping the news agendas

\footnotetext{
$\overline{1}$ Total number of words in the texts.
} 
and influence the contour of public opinion. Therefore, media coverage on these newspapers has a high representativeness of Chinese official discourse. Second, these newspapers contain the largest volume of news texts concerning the COVID-19 outbreak at the national and global levels based on the keyword search at PreQuest and CNKI (Table 2).

Above all, in line with the first step of DHA, we draw on multiple CL tools to establish the key content, themes, and discursive topics in the Chinese and English corpora. Specifically, the text analysis tool KH Coder [34] is used to identify the topfrequency keywords and create the co-occurrence networks of words in the English and Chinese corpora. Before processing the data, we identify a list of stop words (e.g. common words occurring in all kinds of sentences such as substantive verbs) in both Chinese and English corpora and remove them from KH Coder analysis. Additionally, a Chinese language text analysis tool, Ringdata, ${ }^{2}$ is used to create a phrase cloud in the Chinese corpus. The aforementioned CL techniques enable us to identify and compare the most important themes and topics in the English and Chinese corpora. They also contribute to evaluating the relative significance of globalist and nationalist stances in the construction of discursive topics.

With regard to the second phase of DHA, our primary goal is to evaluate how the discursive construction of nationalism and globalism is realized through the use of different discursive strategies. In particular, our analysis focuses on three discursive strategies - nomination, predication, and argumentation - and their relevant linguistic means. For the nationalist and globalist narratives in the news texts, we first select various identity labels—“China/中国," “US/美国," “Europe/欧洲,” and “International or global community/国际社会” — as the "node" of text analysis. Given that the discursive constructions of nationalism and globalism are closely intertwined with the process of constructing the boundary between "us" and "them", we expected that analysing the lexical patterns associated with these identity labels can provide an insight into how Chinese mass media sees the relationships between China and the international community, as well as the relationships between China and the West. We then use $\mathrm{KH}$ Coder to scrutinize the top-frequency collocates and concordance lines associated with these identity labels to examine whether nomination, predication, and argumentation strategies are in place and how these discursive strategies are used to construct China's nationalist and/or globalist stances.

\section{Results and Analysis}

In the first step of DHA, two observations are made. First, by adopting the function of co-occurrence networks of words - to the Chinese and English corpora, we find a high degree of similarity between the Chinese and English texts in the key themes and discursive topics (Figs. 1 and 2). In other words, when reporting the COVID-19 outbreak, the Chinese and English newspapers have focused on similar issues and thus constructed common themes such as "pandemic control," "patients treatment in Hubei province," "medical supplies," "President Xi and central government," and "international cooperation/global community."

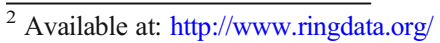


Table 2 The basic news data (January 1 to May 15, 2020)

\begin{tabular}{llllr}
\hline Newspaper & Language & Number of articles & \multicolumn{2}{c}{ Tokens $^{\mathrm{a}}$} \\
\hline English Corpus & People's Daily (人民日报) & Chinese & 126 & 663,329 \\
& Guangming Daily (光明日报) & Chinese & 103 & \\
& Xinhua Daily News (新华每日快讯) & Chinese & 118 & 395,336 \\
Chinese Corpus & China Daily & English & 506 & 263 \\
& Beijing Review & English & & \\
\hline
\end{tabular}

a The process of tokenization is explained by KH Coder Manual. Specifically, KH Coder uses the Standard POS Tagger to lemmatize separated words, and the Snowball Stemmer for stemming. The Snowball Stemmer follows a set of rules in different language. Details of tokenization process can be found at: https://khcoder.net/ en/manual_en_v3.pdf, p.17

Second, the first step of DHA tends to reveal that the frames of globalism appear to be more prominent than nationalism. As mentioned earlier, the primary objective of the first step of DHA is to identify the key content and topics of a given corpus, which provides an overview of the dominant discursive themes in the news texts. According to Charts 1 and 2, an examination of high-frequency words shows a tangible globalist stance. Specifically, “world/世界," “global/全球,” and “international/国际” are among the top 20 frequency words in both Chinese and English corpora. This observation implies that China's news coverage attaches great importance to the COVID-19 outbreak at the global level. Additionally, we adopt $\mathrm{KH}$ Coder to create the cooccurrence network of words in each corpus which enables us to draw a network diagram which demonstrates the words with similar appearance patterns (i.e., with high degree of co-occurrence, connected by lines, as shown in Figs. 1 and 2). As can be seen from Figs. 1 and 2, the co-occurrence networks of words created by KH Coder illustrate that "international, global, cooperation, community, [and the] World Health Organization" are close to each other and connected with lines. As a result, these words constitute a key linguistic cluster or a main discursive theme in the English and Chinese corpora. In other words, international cooperation based on multilateralism stands out as a key discursive theme in both the English and Chinese news texts, reflecting a strong globalist stance.

Moreover, by adopting the tool Ringdata, we create two phrase clouds for the Chinese news corpus, illustrating the top 30 two-word phrases and three-word phrases (Figs. 3 and 4). A similar pattern can be observed: the phrases "international society (国际社会)”, “human destiny (人类命运)”, “WHO (世卫组织/世界卫生组织)”, “a community with a shared future for humanity(人类命运共同体),” and “values of the community with a shared future for humanity (人类命运共同体理念)” have the highest frequency of key phrases in the Chinese language news corpus, which suggests that Chinese corpus highlights the significance of international cooperation, the role of WHO, and the idea of a community with a shared future for humanity. These terms indicate that Chinese news coverage has a salient globalist vision. Although the aforementioned observations reveal a strong globalist sentiment, there is a lack of explicit evidence concerning the construction of a binary "self-versus-other" relationship at this initial stage of DHA. 


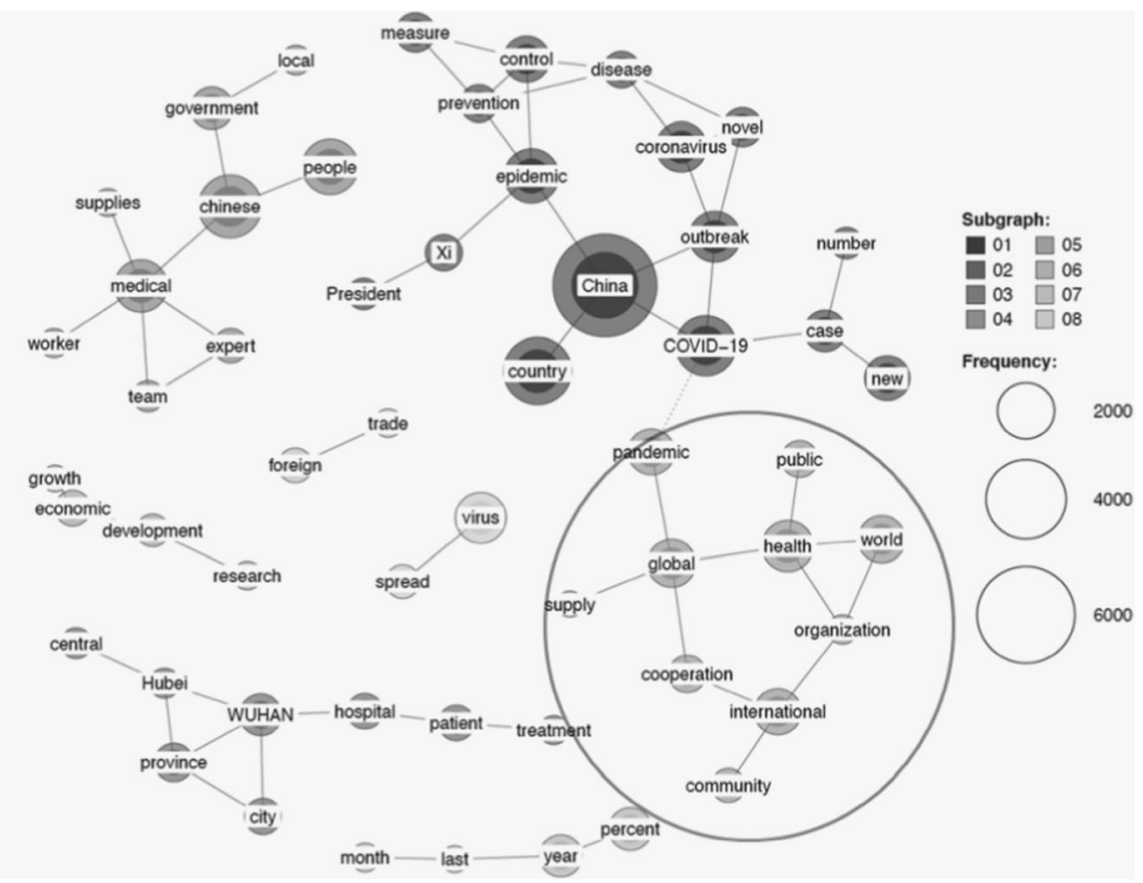

Fig. 1 Co-occurrence network of words in the English corpus

Whilst the first stage of DHA did not explicitly reveal a construction of a binary "self-versus-other" relationship, in the second step of DHA, which examines the deeper linguistic structures and discursive strategies, a more complex picture emerges. We have examined the discursive strategies and linguistic patterns associated with a selected group of identity labels (Table 3 ) in both corpora to disentangle the processes through which nationalism or/and globalism have been discursively constructed. During the second stage of DHA, we observe that the discursive constructions of globalism and nationalism went hand in hand with each other in both corpora. Next, we show that the ultimate objective of the globalist accounts is to reinforce the legitimacy of the ruling party and strengthen the logic of the "us" and "them" dichotomization between China and the West.

\section{Discursive Construction of Globalism}

A combination of nomination, predication, and argumentation discursive strategies are used to establish China as a model in combating the COVID-19 pandemic and construct China as a benign, cooperative, and responsible member of the international community.

Nomination The examination of the noun collocates associated with the label "China/ 中国” reveals a prominent globalist stance. The nomination of China as a successful model in fighting the global pandemic is observed in the Chinese and English corpora. Specifically, China is frequently referred to as “a great and responsible power/负责任 


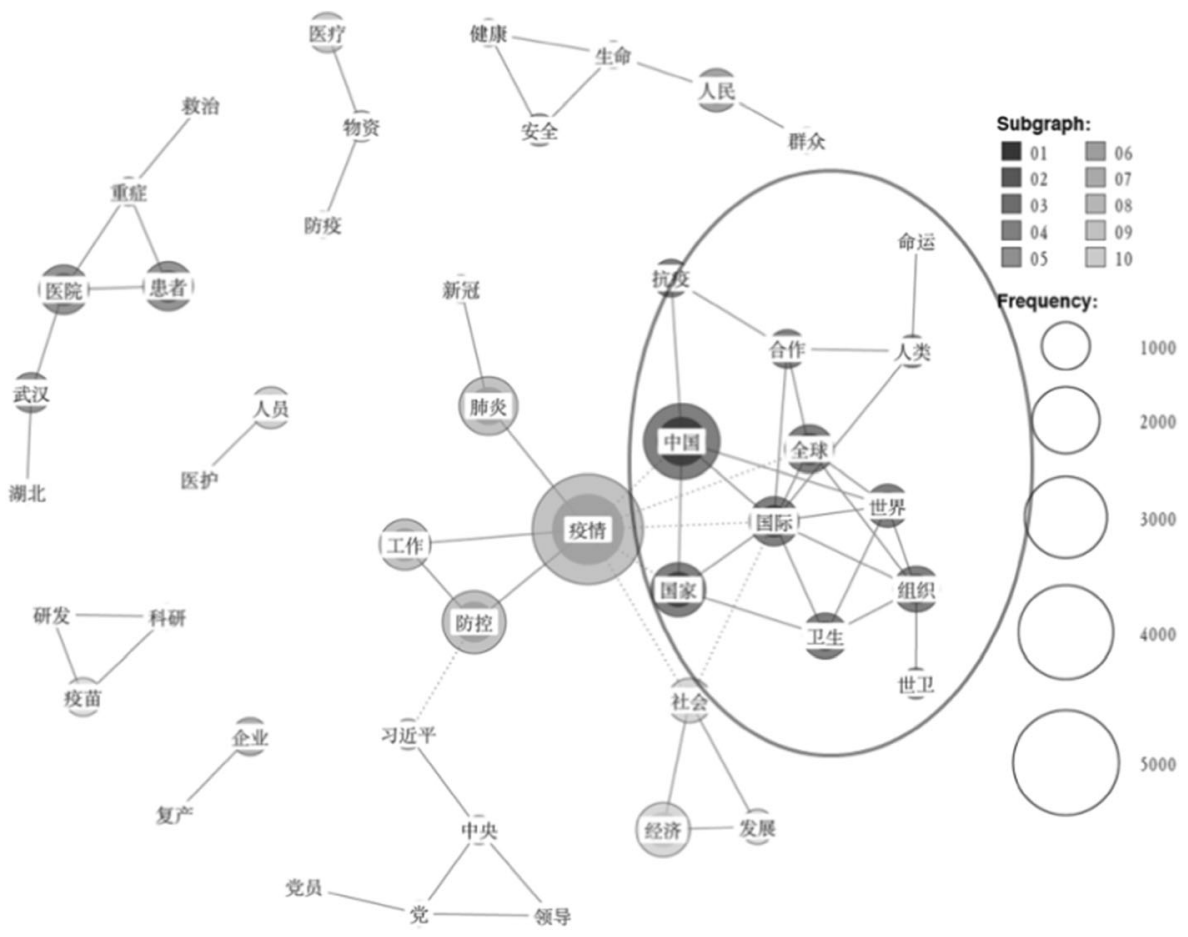

Fig. 2 Co-occurrence network of words in the Chinese corpus

大国” and a source of “智慧(wisdom)”, demonstrating the fitness for a global leadership role. The news texts also emphasize that many "lessons" and "experiences/经验" can be learned by how China is managing COVID-19.

Furthermore, the label “international society/国际社会” is frequently collocated with “a community with a shared future for humanity/人类命运共同体”一 - concept introduced at the 18th National Congress of the CCP in 2012 and subsequently codified as an integral component of President Xi's thought on socialism with Chinese characteristics for the new era. In both corpora, China is constructed as a firm proponent of “international cooperation/国际合作” and “multilateralism/多边主义,” fighting with COVID-19 with the spirit of "building a community with a shared future for humanity 建立人类命运共同体的精神力量.”

Predication For the predication strategy, scrutiny of adjective collocates attached to the label "China/中国” shows that both corpora tend to attribute positive traits and characteristics to China to portray China as a cooperative, benign state willing to support the global community. Overall, China is described as an "important/重要," “effective/有 效,” “responsible/负责任,” and “strong/强大” actor in containing the pandemic. The news texts highlight that China has managed the crisis in a “timely/及时," “open and transparent /公开透” manner. Moreover, because China's achievement in COVID-19 prevention is outstanding (出色/了不起), the Chinese and English corpora stress that Beijing is ready and is willing to cooperate with all parties in the international community to overcome the COVID-19 outbreak. 


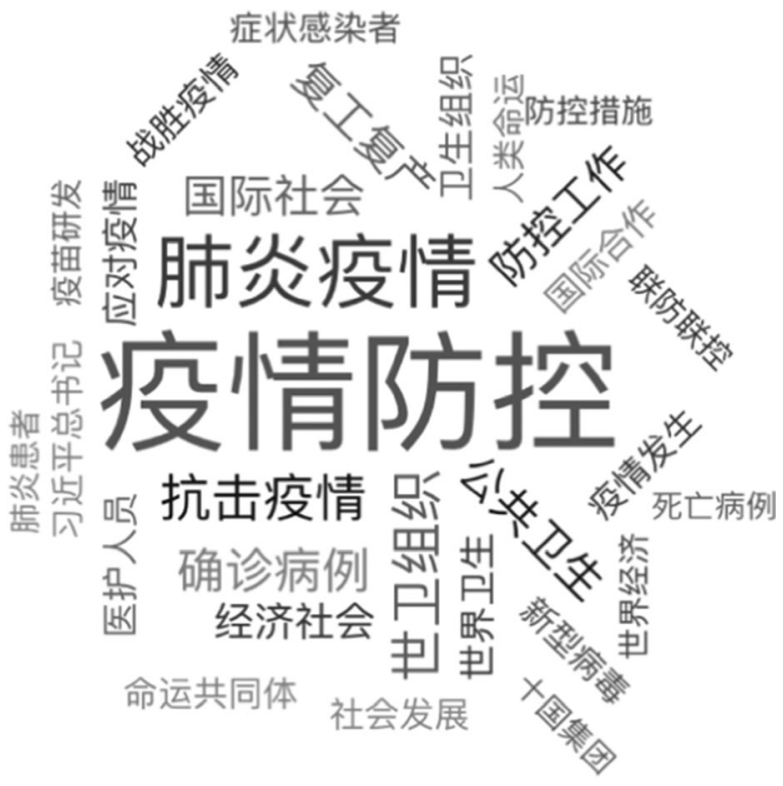

Chart 1 Top 20 keywords with the highest frequency in the English corpus. Source: created by the authors

Argumentation In addition to nomination and predication, the argumentation strategy has been used to construct and reinforce China's globalist stance in the newspapers. By analyzing the concordance lines associated with the labels "China" and "International/ global community" in a qualitative manner, we find that the English and Chinese news

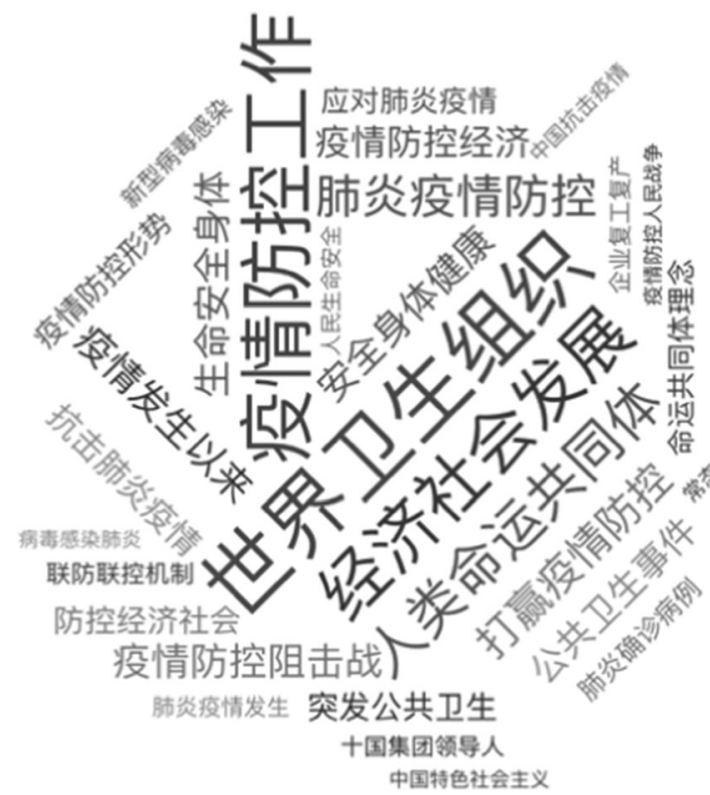

Chart 2 Top 20 keywords with e highest frequency in the Chinese corpus. Source: created by the authors 


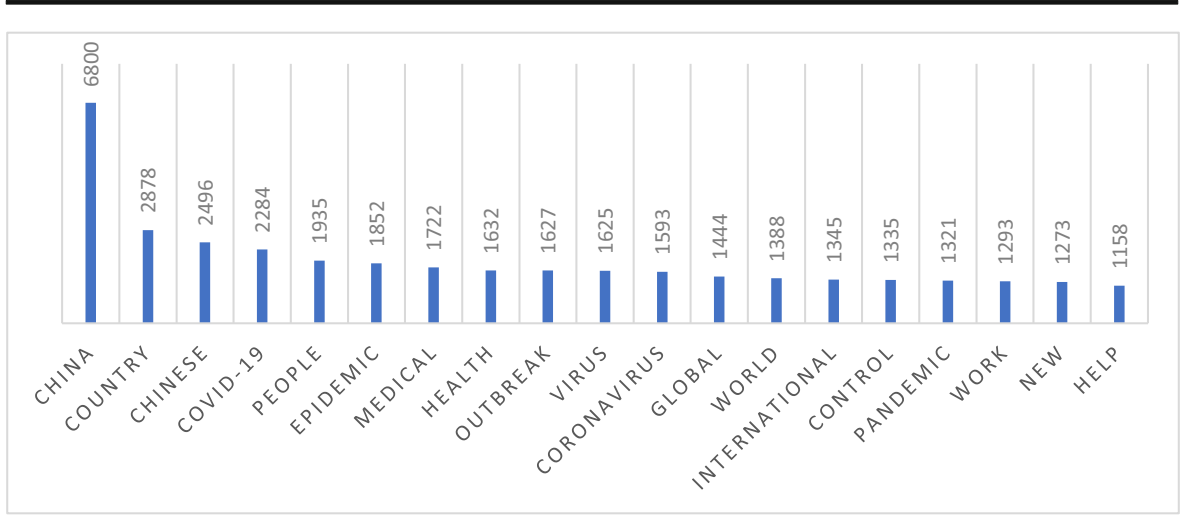

Fig. 3 Phrase Cloud in Chinese corpus (Top 30 high-frequency 2-word phrases)

texts relied on similar topos to justify and legitimize China's pro-globalism attitude (Table 4).

In particular, the topos of reality, usefulness, and opportunity were used to strengthen globalist arguments. For instance, the topoi of reality stressed that China's active cooperation with multilateral institutions and the wider international community in fighting COVID-19 is acknowledged as a "fact" that is "obvious to all." Additionally, the topoi of usefulness were adopted to support the claim that international cooperation and multilateralism is useful for overcoming the global pandemic. For example, the news texts considered "multilateral efforts" and the establishment of "a community with a shared future for mankind" as a precondition for achieving "common health and well-being and a better development prospect."

Furthermore, the topoi of opportunity were used to support the argument that China can offer extra time in the global fight against COVID-19. Specifically, the news texts emphasized that China's economy would become improve after the pandemic, resulting in "development opportunities" for the global community. Additionally, the media reports assumed that China's experiences in controlling the COVID-19 would enable other countries to "seize the opportunity to control the epidemic."

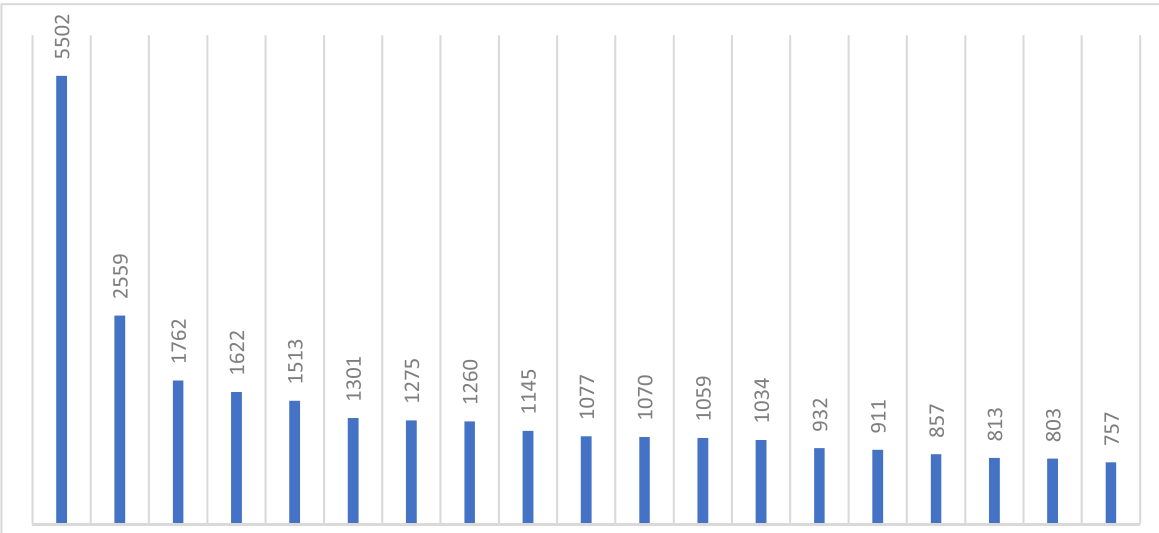

疫情中国防控病毒肺炎国家经济美国工作国际医院患者全球组织卫生社会世界人民人员

Fig. 4 Phrase Cloud in Chinese corpus (Top 30 high-frequency 3-word phrases) 
Table 3 Key identity labels and their frequencies

\begin{tabular}{lllll}
\hline Identity labels & China 中国 & US 美国 & Europe/EU 欧洲/欧盟 & International/Global Community 国际社会 \\
\hline English corpus & 6800 & 767 & 339 & 272 \\
Chinese corpus & 2559 & 1260 & 257 & 301 \\
\hline
\end{tabular}

\section{Discursive Construction of Nationalism}

Despite the salient attitude of globalism, China's media representation of the COVID19 outbreak is characterized by a deliberate construction of a positive selfrepresentation and a negative other-representation based on a binary or antagonistic opposites of us versus them. Similar to the construction of globalism, a combination of nomination, predication, and argumentation strategies is adopted to realize the discursive construction of nationalism in the news corpora. The following paragraphs show how discursive strategies are used to establish the polarizing "self-versus-other" relationship between China and other countries. In particular, the examination of the corpora's data reveals two distinct, interrelated processes of discursive construction through which China attempts to create an antagonistic relationship between a positive self and a negative other: first, the news texts accentuate China's self-congratulations on its success in containing the pandemic while heavily criticizing Western countries' ineffective responses and the West's demonization of China; second, the news corpora portray China as an altruistic international actor in the global fight against the virus while describing the West - especially the United States - as irresponsible actors that undermine the solidarity of the international community.

Nomination Nomination strategy is a technique to describe China's response to the COVID-19 outbreak in a positive, appreciative manner. Nomination is used to establish a negative "other" by labeling Western countries deprecatorily. Scrutiny of the noun collocates and the corresponding concordance lines of “China/中国," “US/美国,” and “Europe/欧洲” reveals evidence of the discursive construction of polarized images of China and the West. For example, when reporting China's measures of pandemic prevention and control, noun collocates such as “achievements /成就," “success /成功," “victory /胜利,” “contribution /贡献,” and “sacrifice/牺牲” are frequently used to praise China's efforts and sacrifices regarding COVID-19, whereas collocates such as “failure /失败," “失控(loss of control)," and “new epicenters of the outbreak / 新震中” are used to depicts the US and European responses.

Predication For the predication strategy, the examination of adjective collocations and relevant concordance lines of the same identity labels reveals similar polarized portraits of China and the West. Whereas China was praised for its "effective/有效," "strong强 大," and “timely/及时” measures of pandemic control and its “enormous(巨大)" sacrifice in the fight against COVID-19, the United States and Europe are referred as the worst-hit, worst-affected, or hardest-hit regions, where the number of cases has sharply “剧烈(sharp)" increased. Additionally, the United States and Europe are criticized for their slow responses and “ineffective/不力”, “erratic” management of the crisis. The 
news texts also criticize Western countries' demonization-especially that of the United States - of China. For instance, the United States is criticized for its intensifying efforts to defame China and for the “失实(untrue)" accusation that China has spread disinformation on the COVID-19 outbreak. Additionally, the news texts tend to depict

Table 4 Topos used to justify China's globalist stance

\begin{tabular}{ll}
\hline Topoi Claim & $\begin{array}{l}\text { Examples (Chinese corpus) Examples (English corpus) } \\
\text { translated by the author }\end{array}$ \\
\hline
\end{tabular}

Reality $\quad$ hina is an active proponent
for globalism and plays an
important role in containing
the worldwide pandemic.

China immediately reported the epidemic situation to WHO, shared the new coronavirus gene sequence with other countries, and cooperated with [the] international community. This was a fact and obvious to all, and was generally praised by the international community

(People's Daily, 27 April 2020).

Usefulness International cooperation or multilateralism is useful for overcoming the pandemic.

It is urgent to increase cooperation on multilateral latitudes and fight the pandemic together with multilateral efforts. Only by building a community with a shared future for mankind can we maintain common health and well-being and a better development prospect (People's Daily, 24 April 2020).

\section{Opportunity China offers window of opportunity in global COVID-19 fight.}

At present, China's economy is gradually returning to the right track, and it is

\section{Ndiaye said the fact that China has shared information with the World Health Organization since the early days of the outbreak has also helped the organization and other governments to better respond to the COVID-19 pandemic (China Daily, 7 May 2020)}

Countries must enhance their consciousness of a community with a shared future for mankind ... closer international cooperation, coordinated policies concerted actions, and mobilization of resources and forces globally will enable us to defeat this virus, a common enemy to all of humanity (China Daily, 20 April 2020) believed that China's economic development after the epidemic will be healthier. China's goal of building a well-off society in an all-round way will not only bring development opportunities to the economies of all countries, but also make a major contribution to the innovation of global governance models

(People's Daily, 13

March 2020).
The international community should seize the opportunity to control the epidemic while China can provide useful and proven experience in fighting it (Beijing Review, 5 March 2020) 
China as a "generous/慷慨” donor making every effort to assist all parties in the world while portraying other countries (especially those in the West, including the United States) as pursuing “selfish/自私” crisis management measures based on geopolitical and strategic calculations. Table 5 offers a summary of the top-frequency adjective collocates associated with China, the United States, and Europe in both corpora.

Argumentation For the argumentation strategy, topos were used to establish an antagonistic relationship between China and the West. In Table 6, the news corpora relied on the topos of threat, uselessness, irresponsibility, and illegality to realize the discursive construction of a negative other. Specifically, the press coverage used the topoi of threat to portray the US actions as a threat to "the overall public health and safety situation." Additionally, the topoi of uselessness and that of irresponsibility stressed that Western countries' responses to the pandemic were generally ineffective; therefore, their ineffectiveness should be blamed. For instance, the media coverage stated that "the US government reacted too slowly to contain the COVID-19" and that "the incompetence of the governments of the US and some European countries is to blame for the high numbers of positive cases and deaths." Last, the topoi of illegality were used to consolidate the media's argument that Western countries-especially the United States-tended to demonize China unlawfully.

\section{Relationships Between Nationalism and Globalism}

Although the aforementioned analysis confirms our assumption that in China's media representation of COVID-19 outbreak, globalism neither contradicts national sovereignty nor is a blanket rejection of national units and commitments. Instead,

Table 5 Key adjective collocates associated with the identity labels "China, the United States, and Europe" based on KH Coder's KWIC Concordance analysis

\begin{tabular}{|c|c|c|c|}
\hline $\begin{array}{l}\text { Identity } \\
\text { label }\end{array}$ & China/中国 & US/美国 & Europe/欧洲 \\
\hline Chinese & corpus & $\begin{array}{l}\text { 透明, 有力, 有效, 重要, 出色, 了不起, } \\
\text { 鲜明, 负责任, 强大 }\end{array}$ & $\begin{array}{l}\text { 严重、不同、不力、冷漠、失 } \\
\text { 实、失望、微薄、残忍、沉 } \\
\text { 重、疯狂、痛心、自大 }\end{array}$ \\
\hline 严重、剧 & $\begin{array}{l}\text { 烈、迅猛、异常、严峻、平 } \\
\text { 缓、相似、缓慢 }\end{array}$ & & \\
\hline \multirow[t]{2}{*}{ English } & corpus & $\begin{array}{l}\text { International, global, willing, } \\
\text { ready, timely, positive, } \\
\text { effective, responsible, } \\
\text { comprehensive }\end{array}$ & $\begin{array}{l}\text { Former, senior, presidential, } \\
\text { ineffective, erratic, } \\
\text { irresponsible, unwilling, } \\
\text { volatile, provocative, } \\
\text { worst-hit }\end{array}$ \\
\hline & $\begin{array}{l}\text { Worst-hit, illusionary, } \\
\text { worst-affected, slower, } \\
\text { disruptive, affected, } \\
\text { reciprocal, hardest-hit }\end{array}$ & & \\
\hline
\end{tabular}

These adjective collocates are selected based on KH Coder's KWIC Concordance analysis which uses the scale of Mutual Information to indicate the collocation between the node words (i.e. identity labels) and their adjective collocates 
Table 6 Topos used to construct a negative "other"

\begin{tabular}{|c|c|c|c|}
\hline Topoi & Claim & $\begin{array}{l}\text { Examples (Chinese corpus) } \\
\text { Translated by the authors }\end{array}$ & Examples (English corpus) \\
\hline Threat & $\begin{array}{l}\text { Actions taken by the United } \\
\text { States threaten the global } \\
\text { community. }\end{array}$ & $\begin{array}{l}\text { "What the US has done } \\
\text { seriously damages the } \\
\text { rights of its people, } \\
\text { hinders the international } \\
\text { community's joint efforts } \\
\text { to fight the epidemic, and } \\
\text { threatens the overall } \\
\text { public health and safety } \\
\text { situation" } \\
\text { (Xinhua Daily News, } 1 \\
\text { May 2020) }\end{array}$ & $\begin{array}{l}\text { "Even as the US and the } \\
\text { world face a worsening } \\
\text { pandemic, some } \\
\text { Washington elites are still } \\
\text { seeking to intensify the } \\
\text { confrontation between } \\
\text { China and the US" (China } \\
\text { Daily, } 30 \text { March 2020) }\end{array}$ \\
\hline $\begin{array}{l}\text { Uselessness/ } \\
\text { disadvantage }\end{array}$ & $\begin{array}{l}\text { Western countries are in a } \\
\text { serious situation and their } \\
\text { responses to the pandemic } \\
\text { have been slow and } \\
\text { ineffective. }\end{array}$ & $\begin{array}{l}\text { "Since the beginning of } \\
\text { March, the new coronary } \\
\text { pneumonia epidemic has } \\
\text { swept across Europe and } \\
\text { has had a disastrous } \\
\text { impact on most } \\
\text { countries"(People's Daily, } \\
26 \text { April 2020) }\end{array}$ & $\begin{array}{l}\text { The US government reacted } \\
\text { too slowly to contain the } \\
\text { COVID-19 pandemic as } \\
\text { the virus was spreading } \\
\text { from Europe, which led to } \\
\text { the surge of infections and } \\
\text { deaths in the country, a } \\
\text { top official at the US } \\
\text { Centers for Disease Con- } \\
\text { trol and Prevention said } \\
\text { (Beijing Review, May 4, } \\
\text { 2020) }\end{array}$ \\
\hline Irresponsibility & $\begin{array}{l}\text { The United States and some } \\
\text { European countries should } \\
\text { take more responsibility in } \\
\text { fighting the virus, and } \\
\text { their incompetence should } \\
\text { be blamed. }\end{array}$ & $\begin{array}{l}\text { "Experts and media from } \\
\text { many countries have } \\
\text { recently pointed out that } \\
\text { the Trump } \\
\text { administration's } \\
\text { ineffective response has } \\
\text { caused the United States } \\
\text { to become the most } \\
\text { serious country in the } \\
\text { world's new crown } \\
\text { epidemic." (Xinhua Daily } \\
\text { News, 1 May 2020) }\end{array}$ & $\begin{array}{l}\text { "the incompetence of the } \\
\text { governments of the US } \\
\text { and some European } \\
\text { countries is to blame for } \\
\text { the high numbers of } \\
\text { positive cases and deaths } \\
\text { there" (China Daily, } 9 \\
\text { May 2020) }\end{array}$ \\
\hline Illegality & $\begin{array}{l}\text { According to the Chinese } \\
\text { media, the West's } \\
\text { demonization of China is } \\
\text { at odds with international } \\
\text { law. }\end{array}$ & $\begin{array}{l}\text { "In accordance with } \\
\text { international law, } \\
\text { emergencies and other } \\
\text { public health emergencies } \\
\text { are legally force majeure. } \\
\text { The absurd dramas } \\
\text { performed by some } \\
\text { politicians in the United } \\
\text { States will not help control } \\
\text { the epidemic and reduce } \\
\text { deaths." (Xinhua Daily } \\
\text { News, } 5 \text { May 2020) }\end{array}$ & $\begin{array}{l}\text { "Yet the claims of US } \\
\text { politicians that China } \\
\text { should take the } \\
\text { responsibility for the } \\
\text { pandemic are untenable in } \\
\text { law" } \\
\text { (China Daily, } 22 \text { April 2020) }\end{array}$ \\
\hline
\end{tabular}


nationalism and globalism co-exist in both news corpora. Next, we examine the relationships between China's nationalist and globalist stances in the context of this research.

Based on a closer examination of the concordance lines and paragraphs associated with the key identity labels, we observed that on many occasions, the globalist and nationalist arguments were closely intertwined and complement each other to reinforce the legitimacy of the $\mathrm{CCP}$ at home. Excerpt 1 represents a telling example of how globalism and nationalism are closely linked and serve a similar purpose of portraying China as a powerful, responsible state in the international community. In Excerpt 1, the globalist stance is obvious because the news texts emphasized China's capability and willingness to provide assistance to the global community. Nevertheless, the paragraph also reveals a strong nationalist stance by discursively constructing the logic of positive "self" and negative "other."

\section{Excerpt 1:}

At present, I am quite disappointed with the performance of the United States in this epidemic. Since World War II, the United States has been recognized globally, not only because of its strong economic and military strength, but also because it provided a lot of public goods in previous crises, but this time it did not, because the United States is still under the influence of the "American Priority Theory" and unilateralism. China can do more in this regard, demonstrating the style of great powers. Recently, China donated 1,000 ventilators to New York State, USA. The American people are grateful that China has the ability to provide assistance within its ability to more countries in crisis. The United States has problems in this regard. (16 April 2020, Guangming Daily, translated by the authors)

We observe a similar pattern in Excerpt 2, in which globalism and nationalism are detected. On the one hand, globalism was evidenced in the paragraph, which accentuated China's active role in providing material support to the US in its fight against the virus. On the other hand, we observe nationalism in the news coverage's portrayal of the United States as a negative "other". The ultimate objective of the globalist and nationalist discursive practices is to strengthen the CCP's domestic legitimacy and promote China's international reputation on the global stage.

\section{Excerpt 2:}

Despite the US administration's continuous and organized attacks on it, China has never ceased providing assistance to the country. As of last week, China had provided the US with about 2.5 billion face masks, and 5,000 ventilators, making it the largest material supporter of the US in its fight against the virus. To save lives must be its priority. With one-third of the world's infections and one-fourth of the world's deaths caused by the virus being recorded on US soil, those advisers, who feel no qualms about earning money from trying to keep the US administration in its comfort zone, should be ashamed that they are in effect taking blood money (China Daily, 27 April 2020). 


\section{Discussion and Conclusion}

By employing DHA and CL, this paper has examined the Chinese media representation of the COVID-19 outbreak and found both globalism and nationalism in China's official media discourse. A globalist stance is more evident in newspapers published in Chinese and English, since the Chinese official media highly support international cooperation in combating the COVID-19. Meanwhile, nationalism as a sentiment or consciousness of belonging to the nation is presented by in Chinese media discourse as well praising China, blaming the US and lecturing the EU when reporting the COVID19 outbreak. In particular, it firstly seems that a paradox of globalism at one extreme and nationalism at the opposite extreme co-exist in official discourse. Secondly, the globalist discourse has been constructed in a nationalist manner. These findings suggest China, on the one hand, supports international cooperation but, on the other hand, might generate more suspicion vis-à-vis the West by criticizing Western countries who are supposed to be cooperated with. Due to the media ecology in China, the official media outlets portray China as a cooperative, responsible power in combating the global pandemic relative to some irresponsible, incapable Western powers such as the United States, which has been reflected in both globalist and nationalist discourses in the context of the COVID-19 outbreak. While the simultaneous promotion of globalism and nationalism appears to be paradoxical at first, the discursive constructions of globalism and nationalism go hand in hand with each other [37, 43], as both are constructed based on the same logic of the "us" and "them" dichotomization and harmonized in sustaining the legitimacy of the CCP at home and enhancing the international reputation of China under the leadership of the $\mathrm{CCP}$ on the world stage [53].

While the existing literature suggests that that audience design influences and determines the choice of concepts and words familiar to the target audience [45], the Chinese English-language media has never intended to address the distinctiveness of international audiences because the discursive content in the English corpus is merely a mirror of the Chinese news texts. In other words, as an inward-looking country, dealing with internal problems without losing the control of the CCP and enhancing the legitimacy of the ruling party at home has been prioritized in China's official media outlets. This is particularly the case during public health crises that might lead to the loss of credibility of the government and the legitimacy of the CCP. Therefore, on the one hand, a globalist discourse is evident in stressing multilateralism/global governance in comparison with the conservative and even selfish behaviors of Western countries. On the other hand, nationalist stances are reflected in the discourse of selfcongratulations relative to the inefficiency and incapacity of Western countries. Both are targeting the domestic audience rather than international readers.

However, this is not to exclude China's active participation in global governance. China's growing dissatisfaction with the current international system has been further increased by some Western countries' accusations and demonization of China and its political system when combating the global pandemic. This has been attributed to China's weakness in discourse rights in international politics. By portraying China as a defender of multilateralism and global governance and a cooperative, responsible international player through official media outlets, it to some extent shows China's intention to reassure its influence proportional to its growing power. Consequently, 
COVID-19 may be an opportunity for Chinese statecraft in managing with internal and external challenges.

\section{References}

1. Albrow, M. 1996. The global age: State and society beyond modernity. Cambridge: Polity Press.

2. Aydın-Düzgit, S. 2014. Critical discourse analysis in analysing European Union foreign policy. Cooperation and Conflict 49 (3): 354-367.

3. Baker, P., 2007. Discourses of refugees and asylum seekers in the UK press, 1996-2006: Full Research Report. ESRC End of Award Report, RES-000-22-1381. Swindon: ESRC.

4. Baker, P., McEnery, T. and Gabrielatos, C., 2007. Using collocation analysis to reveal the construction of minority groups. Corpus Linguistics 2007, https://eprints.lancs.ac.uk/id/eprint/602/

5. Baker, P., C. Gabrielatos, M. Khosravinik, M. Krzyżanowski, T. McEnery, and R. Wodak. 2008. A useful methodological synergy? Discourse \& Society 19 (3): 273-306.

6. Barbieri, G. 2019. Regionalism, globalism and complexity: A stimulus towards global IR? Third World Thematics: A TWQ Journal 4 (6): 424-441.

7. Benwell, B., and E. Stokoe. 2006. Discourse and identity. Edinburgh: Edinburgh University Press.

8. Boon, H.T. 2018. China's global identity. Washington, DC: Georgetown University Press.

9. Brown, K., and R.C. Wang. 2020. Politics and science: The case of China and the coronavirus. Asian Affairs 51: 247-264. https://doi.org/10.1080/03068374.2020.1752567.

10. Cahan, J.A. 2019. National identity and the limits of constructivism in international relations theory. Nations and Nationalism 25 (2): 478-498.

11. Cai, T. 2016. Global governance and state governance. Social Sciences in China 37 (4): 138-151.

12. Chan, G. 2014. Capturing China's international identity. The Chinese Journal of International Politics 7 (2): 261-281.

13. Chen, Z. 2005. Nationalism, internationalism and Chinese foreign policy. Journal of Contemporary China 14 (42): 35-53.

14. Cho, Y.C., and Y. Hwang. 2020. Mainstream IR theoretical perspectives and rising China Vis-À-Vis the west: The logic of conquest, conversion and socialisation. Journal of Chinese Political Science 25 (2): 175-198.

15. Chouliaraki, L. 2000. Political discourse in the news: Democratizing responsibility or aestheticizing politics? Discourse \& Society 11 (3): 293-314.

16. Çinar, A. 2010. Globalism as the product of nationalism: Founding ideology and the erasure of the local in Turkey. Theory, Culture \& Society 27 (4): 90-118.

17. Dubravčíková, K. 2020. China's story about COVID-19: China to praise, America to blame, Europe to learn. China Media Watch by Central European Institute of Asian Studies Access Jul. 25, 2020, https:// ceias.eu/chinas-story-about-covid-19-china-to-praise-america-to-blame-europe-to-learn/.

18. Erlanger, S. 2020. Global backlash builds against China over coronavirus, The New York Times, Access June 7, 2020, https://www.nytimes.com/2020/05/03/world/europe/backlash-china-coronavirus.html.

19. Ershov, Y.M. 2015. National identity in new media. Procedia-Social and Behavioral Science. 200: 206209.

20. Evans, D. 2015. Introduction. In Language and Identity: Discourse in the world, ed. David Evans, 3-14. London and New York: Bloomsbury.

21. Fairclough, N. 2010. Critical discourse analysis: The critical study of language. 2nd ed. London and New York: Routledge.

22. Freake, R., G. Gentil, and J. Sheyholislami. 2011. A bilingual corpus-assisted discourse study of the construction of nationhood and belonging in Quebec. Discourse \& Society 22 (1): 21-47.

23. Gifford, R. 2011. China's rise: Inward-looking or expansionist? NPR.org Access Jul. 25, 2020, https:// www.npr.org/2011/06/30/137460232/chinas-rise-inward-looking-or-expansionist.

24. Gu, Y., X. Qin, Z. Wang, C. Zhang, and S. Guo. 2020. Global justice index report. Chinese Political Science Review 5 (3): 253-331.

25. Hall, A. 2000. The mass media, cultural identity and perceptions of national character. International Communication Gazette 62 (3-4): 231-249.

26. Han, L. 2011. "Lucky cloud" over the world: The journalistic discourse of nationalism beyond China in the Beijing Olympics global torch relay. Critical Studies in Media Communication 28 (4): 275-291. 
27. He, Y. 2018. Domestic troubles, national identity discourse, and China's attitude towards the west, 20032012. Nations and Nationalism. 24 (3): 741-766.

28. He, A., Y. Shi, and H. Liu. 2020. Crisis governance, Chinese style: Distinctive feature of China's response to the Covid-19 pandemic. Journal of Policy Design and Practice: 1-17. https://doi.org/10. 1080/25741292.2020.1799911.

29. Hester, S., and W. Housley. 2002. Ethnomethodology and national identity. In Language, Interaction and National Identity, ed. Stephen Hester and William Housley, 1-15. Hants: Ashgate.

30. James, P. 2006. Globalism, nationalism, tribalism: Bringing theory back in. London, Thousand Oaks, New Delhi: Sage Publications.

31. Karl, T.L. 2019. Extreme inequality and state capture: The crisis of Liberal democracy in the United States. Chinese Political Science Review 4 (2): 149-163.

32. Kerckem, K.V. 2016. "How can I feel Belgian if Belgians don't accept me?": Ethnic boundary perception and national identity among Turkish Belgians. In National identity: Theory and research, ed. Richard R. Verdugo and Andrew Milne, 273-310. Charlotte, NC: Information Age Publishing.

33. Kim, J. 2020. The Chinese people step up to enforce China's nationalist propaganda. The Diplomat Access May 13, 2020, https://thediplomat.com/2020/05/the-chinese-people-step-up-to-enforce-chinasnationalist-propaganda/.

34. Koichi, H., 2017. KH Coder, Open source software, Ritsumeikan University, Japan. http://khcoder.net/ en/

35. Koller, V., and G. Mautner. 2004. Computer applications in critical discourse analysis. In Applying English grammar: Corpus and functional approaches, ed. C. Coffin, A. Hewings, and K. O'Halloran, 216-228. London: Arnold.

36. Kowert, P.A. 1998. National identity: Inside and outside. Security Studies 8 (2-3): 1-34.

37. Lai, B.H., and N.F. Martini. 2020. Nationalism and its effects on attitudes about trade, cooperation and immigration. Fudan Journal of the Humanities and Social Sciences. https://doi.org/10.1007/s40647-02000289-0.

38. Lams, L. 2017. Othering in Chinese official media narratives during diplomatic standoffs with the US and Japan. Palgrave Communications 3 (1): 1-11.

39. Legrain, P. 2020. The coronavirus is killing globalization as we know it. Foreign Policy Access May 21, 2020, https://foreignpolicy.com/2020/03/12/coronavirus-killing-globalization-nationalism-protectionismtrump/.

40. Li, J. 2009. Intertextuality and national identity. Discourse \& Society 20 (1): 85-121.

41. Lu, J., and X. Yu. 2018. The internet as a context: Exploring its impacts on national identity in 36 countries. Social Science Computer Review 37 (6): 705-722.

42. Madianou, M. 2011. Mediating the nation: News, audiences and the politics of identity. London and New York: Routledge.

43. Mikecz, R. 2019. The cornerstone of economic nationalism: National self-image. Fudan Journal of the Humanities and Social Sciences 12 (4): 587-608.

44. Müller, P. 2016. National identity building as a mediated process. In Dynamics of National Identity: Media and social factors of what we are, ed. Jürgen Grimm, Leonie Huddy, Peter Schmidt, and Josef Seethaler, 319-333. London and New York: Routledge.

45. Ng, S.H., J. Ye, and C. Lee. 2011. Media discourse on globalization in China. Journal of Language and Social Psychology 30 (2): 139-157.

46. Nye, J. 2002. Globalism versus globalization. The Globalists Access May 21, 2020, https://www. theglobalist.com/globalism-versus-globalization/.

47. Parekh, B. 1994. Discourse on National Identity. Political Studies 42: 492-504.

48. Prentice, S. 2010. Using automated semantic tagging in critical discourse analysis. Discourse \& Society 21 (4): 405-437.

49. Reisigl, M., and R.E. Wodak. 2015. The discourse-historical approach (DHA). In Methods of critical discourse studies. $3^{\text {rd }}$ edition, Introducing Qualitative Methods, ed. R. Wodak and M. Meyer, 23-61. London: Sage.

50. Shambaugh, D. 2011. Coping with a conflicted China. The Washington Quarterly 34 (1): 7-27.

51. Shirk, S. 2011. Changing media, changing China. In Changing media, changing China, ed. Susan Shirk, 1-37. New York: Oxford University Press.

52. Smith, A.D. 2010. Nationalism: Theory, ideology, history. 2nd ed. Cambridge: Polity Press.

53. Song, Y., C. Lee, and Z. Huang. 2019. The news prism of nationalism versus globalism: How does the US, UK and Chinese elite press cover 'China's rise'? Journalism. https://doi.org/10.1177/ 1464884919847143. 
54. Stockmann, D., and M. Gallagher. 2011. Remote control: How the media sustain authoritarian rule in China. Comparative Political Studies 44 (4): 436-467.

55. Tocci, N. 2020. The COVID-19 global inflection point and Europe's predicament. Asia Europe Journal 18: 227-229. https://doi.org/10.1007/s10308-020-00573-4.

56. Tu, X., Y. du, Y. Lu, and C. Lou. 2020. US-China trade war: Is winter coming for global trade? Journal of Chinese Political Science 25 (2): 199-240.

57. Verma, R. 2020. China's "mask diplomacy" to change the COVID-19 narrative in Europe. Asia Europe Journal 18: 205-209. https://doi.org/10.1007/s10308-020-00576-1.

58. Wang, Z., and J. Zeng. 2020. From economic cooperation to strategic competition: Understanding the US-China trade disputes through the transformed relations. Journal of Chinese Political Science 25 (1): 49-69.

59. Wodak, R., and M. Meyer, eds. 2009. Methods for critical discourse analysis. London: SAGE.

60. Xi, J. 2020. Fighting COVID-19 through solidarity and cooperation, building a global community of health for all. Statement by H.E. Xi Jinping, President of the People's Republic of China at Virtual Event of Opening of the 73rd World Health Assembly, Ministry of Foreign Affairs of the People's Republic of China Access June 4, 2020, https://www.fmprc.gov.cn/mfa_eng/zxxx_662805/t1780221.shtml.

61. Yang, Y. 2020. Looking inward: How does Chinese public diplomacy work at home? British Journal of Politics and International Relations 22: 369-386. https://doi.org/10.1177/1369148120917583.

62. Zeng, J. 2019. Chinese views of global economic governance. Third World Quarterly 40 (3): 578-594.

63. Zhang, M. 2020. Dispel clouds of pandemic through cooperation. Asia Europe Journal 18: 197-199. https://doi.org/10.1007/s10308-020-00583-2.

64. Zhao, S. 2000. Chinese nationalism and its international orientations. Political Science Quarterly 115 (1): $1-33$.

65. Zhao, K. 2016. China's rise and its discursive power strategy. Chinese Political Science Review 1 (3): 539-564.

66. Zheng, Y. 2004. Globalization and state transformation in China. Cambridge: Cambridge University Press.

67. Zhu, Y. 2011. "Performance legitimacy" and China's political adaptation strategy. Journal of Chinese Political Science 16 (2): 123-140.

68. Zhu, Z. 2020. "Wolf-warrior diplomacy": China's new normal? Think China Access May 21, 2020, https://www.thinkchina.sg/wolf-warrior-diplomacy-chinas-new-normal.

Yifan Yang currently work as a Research Associate in Politics and International Relations at the Department of Politics, East China Normal University. He holds a PhD degree in International Political Economy from King's College London, and his research lies in the field of Chinese Foreign Policy, EU-China Relations and the impact of ICTs on Chinese Politics/Society. His academic papers have appeared in British Journal of Politics and International Relations, Journal of Contemporary China, Journal of European Integration among others.

Xuechen Chen currently works as a Lecturer in Politics and International Relations at the New College of the Humanities (London). She recently passed her PhD thesis at King's College London. Her research interests lie in the field of EU-Asia Pacific relations, EU foreign policy, comparative regionalism and Chinese foreign policy. 